\title{
Household Cash Expenditure by Living Standards Measure Group
}

JH Martins

\section{OPSOMMING}

Huishoudings kan op grond van 'n verskeidenheid van faktore in verskillende lewenstandaardgroepe ingedeel word. Die artikel gee 'n beskrywing van sommige van die maatstawwe wat gebruik kan word vir so ' $n$ indeling en verduidelik daarna die maatstawwe wat deur die Suid-Afrikaanse Reklamenavorsingstigting (SARNS) neergelê word vir 'n indeling in tien groepe volgens SARNS se Lewenstandaarde Metingsmodel. Die grondslag van die model is die besit van huishoudelike bates, toegang tot geselekteerde dienste (water, elektrisiteit, sanitasie, ens) en die geografiese gebied waar die huishouding woon. Totale huishoudingsbesteding van elkeen van die tien groepe word bereken deur die gemiddelde huishoudingsbesteding te vermenigvuldig met die getal huishoudings in die groep. Daarna word ' $n$ vergelyking in die artikel gemaak van die aandeel van elk van die tien groepe in totale besteding aan 22 hoof bestedingsgroepe. Na die bespreking van totale besteding word die bestedingspatrone van huishoudings wat in die laagste, middel- en hoogste lewenstandaardgroepe geklassifiseer word, geanaliseer om verskille in hulle huishoudingsbegrotings uit te wys. Die items waarop die meeste geld gespandeer word word aangedui. Die bestedingspatroon van die laagste lewenstandaardgroep, huishoudingsgroep 1 , dui daarop dat omtrent al hulle geld aan basiese lewensmiddelle bestee word. Daarteenoor het die middel lewenstandaardgroep, groep 6 , genoeg fondse beskikbaar om behalwe lewensnoodsaaklike lewensmiddelle ook sekere luukshede aan te koop terwyl groep 10, die hoogste groep, aansienlike fondse vir diskresionêre aankope tot hulle beskikking het.
\end{abstract}

- Prof Johan H Martins

University of South Africa

\section{INTRODUCTION}

The objective of this article is to illustrate what households falling into different living standards groups spend their money on and what share their spending contributes to total household cash expenditure in South Africa. Numerous researchers, analysts and observers use the term "living standards" to denote a variety of human conditions and levels of welfare. Some of these, as well as the yardstick for the classification of households, will be discussed prior to explaining the method of obtaining the data for this article and the results of the study. Only cash expenditure and not total household expenditure, which consists of cash and in-kind expenditure, is calculated. In-kind expenditure is made up of goods and services received in kind from employers and social and religious organisations as well as imputed rent. Imputed rent is the calculated rent that an owner could receive from a dwelling unit if not occupied by him/herself, less compulsory payments to the local authority and interest on a bond.

\section{DEFINING LIVING STANDARDS}

Classical examples defining living standards are, inter alia:

- Plato (427 - 347 BC) in The Republic (Plato, 1983:115-125) refers to 'living standards' as the level to which a person's needs have been fulfilled. $\mathrm{He}$ includes under the term 'need' the need for food, shelter and clothes.

- Aristotle (384 - 322 BC) (Abraham, 1977:35-39) refers to the term 'living standards' as the socioeconomic condition of a person as reflected by his social class. He identifies three such classes, namely the very poor, the middle class and the very wealthy.

- Ibn Khaldun (1332 - 1406) (Abraham, 1977:39-43), in his famous work Prolegomena, used the term 'living standards' to refer to the level of skills a person has enabling him/her to enjoy a good lifestyle.

- Charles de Secondat (1689 - 1755) (Abraham, 1977:57-71) used the term 'living standards' to refer to the level of 'fortune' a person was enjoying. De Secondat (better known as Montesquieu) classified nations and people according to on the level of 'luxury' they enjoyed.

- Karl Marx (1818 - 1883) (Marx, 1981) used the term 'living standards' to denote the level at which people were able to accumulate capital and to improve their living conditions by using such income for food, housing, clothing, education, et cetera.

- John Maynard Keynes (Keynes, 1936:Online) 
used the term 'living standards' to differentiate between different levels of wealth transfer. In his famous work, The general theory of employment, interest and money, Keynes opined that a person's level of consumption is determined by his/her income. The higher the income of a person, the more he/she can consume and thus the higher such a person's living standard would be.

- Robert Summers and Alan Heston (Summers and Heston, 1995:1-4) use the term 'living standards' to refer to the levels of material well-being of people and countries.

\section{CLASSIFICATION OF PEOPLE INTO DIFFERENT LIVING STANDARD GROUPS}

In their monograph entitled Standard of living: An alternative measure of nations' current material wellbeing, Summers and Heston (1995:1-4) describe the living standards measure as a 'new index of social welfare' that renders different results about wealth distribution compared to wealth distribution results based on income measures.

Summers and Heston (1995:1-4) emphasise that generally, social welfare is made up of a substantial number of social, economic and other variables that cannot all be captured in a single index. Rather, the living standard index comprises a limited selection of variables that can be used to explain as accurately as possible a high percentage of the variance space regarding social welfare.

Narayan, Chambers et al (2000:46-70) explored the multi-variable nature of living standards and found that variables that are good predictors of high living standards in one country are not necessarily the same for other countries. In Malawi predictors of high living standards include the usual ones such as certain assets, adequate food, medical care, income, clothes, bedding, a decent house, a toilet, a bathroom and a kitchen, but they also include qualitative variables such as 'peace of mind' and 'respect'. In rural Bangladesh a strong predictor of living standards is having employment for the whole year, a good house, a few cows, a fishing net and protection against floods. In rural Indonesia another variable is added, namely the ability to give material assistance to others (Narayan, Chambers et al, 2000:46-70).

When evaluating the living standards of people in $\mathrm{Ni}$ geria, apart from the usual household variables that need to be taken into account, indicators such as independence, popularity, being in a position to patronise private clinics and schools, having good clothes, property and money also come into play. In the Kyrgyz Republic there is a belief that should you have all the wealth in the world and you do not have tolerance, peace, a family and children, you experience low living standards (Naragan, Chambers et al, 2000:25).

Although there are differences across countries with regard to what is meant by living standards, Narayan, Chambers et al (2000:21-45) identified the following indicators of living standards as being fairly universal:

- having adequate food

- having adequate assets

- having work in order to derive an income

- being healthy and appearing well

- being able to marry and care for children

- having self respect and dignity

- experiencing peace and harmony

- experiencing a physically safe and secure environment

- being confident of the future

- having freedom of choice and action.

Narayan, Patel et al (2000:48-61) summarised the abovementioned universal aspects of living standards into four categories, namely:

- Physical capital: This includes, inter alia, land and material possessions.

- Human capital: This includes, inter alia, access to healthcare, education and training, and a person's labour power.

- Social capital: This includes, inter alia, social networks, support groups and associations.

- Environmental capital: This includes, inter alia, grass, water, trees, fish and animals.

Since the South African Living Standards Measure (LSM) groups focused on in this article do not include human, social and environmental capital as descriptors of living standards, attention will only be given to physical capital as a backdrop to classify households by LSM group.

Of all the aspects of physical capital that are predictors of living standards, ownership of or access to land is often cited as a key asset (Narayan, Patel et al, 2000:48-61). The case of Ecuador clearly demonstrates that if you do not have access to land your living standards will be low. More specifically, rural people need access to land in order to cultivate food. In this regard the condition of the land should preferably be such that they are able to sustain themselves and not live in poverty.

The second physical asset that is frequently mentioned as a strong descriptor of living standards, is housing. According to Narayan, Patel et al (2000:4861) there appears to be a correlation between living standards and housing, namely the better a person's housing, the higher his/her living standard. For the poor, substandard housing can be a liability and a reason for insecurity. For example, in Georgia the poor are exposed to dangerous housing with leaking roofs, cracking walls, rotting floors and rusted pipes. In Bangladesh the thatched huts in which poor people live, are easily destroyed by strong winds and floods (Narayan, Patel et al, 2000:48-61). However, housing could also be an income generator for households, for example, in Swaziland many poor families subsist by renting out rooms in their houses. Seven of the 29 predictor variables of the SAARF LSM concept that are used in this article and will be explained later fall into the housing category.

A third physical capital predictor of living standards is 
personal or household property. This features very strongly in the SAARF LSMs, with 18 of the 29 predictor variables falling into this category.

The South African Advertising Research Foundation (SAARF) Living Standards Measure (LSM) originated during the late 1980s when SAARF considered using a combination of variables to formulate a segmentation tool for South Africa (SAARF, 2005). The original SAARF LSMs were revised from time to time and, finally, during 2001 the so-called 'SAARF Universal Living Standards Measure' concept was introduced. Whereas the 1989 to 2000 LSMs comprised 8 LSM groups, the SAARF Universal LSM (SU-LSM) concept was extended to comprise 10 LSMs based on a total of 29 variables. They are hot running water; fridge/ freezer; microwave oven; flush toilet in house or on plot; VCR in household; vacuum cleaner/floor polisher; washing machine; computer at home; electric stove; television set(s); tumble dryer; Telkom telephone; hi-fi/music centre; built-in kitchen sink; home security service; deep freeze; water in home or on stand; M-Net and/or DSTV; dishwasher; metropolitan dweller; sewing machine; DVD player; house/cluster/ townhouse; one or more motor vehicles; domestic worker; one cellular phone; radio; no cellular phone in household; and living in a non-urban area (SAARF Segmentation Handbook, 2005 on CDROM).

\section{SURVEY METHODOLOGY}

Face-to-face personal interviews amongst 1441 households were conducted by trained fieldworkers in Gauteng, the Western Cape and KwaZulu-Natal using a structured questionnaire. A household consists of one or more people dependent on a common or pooled income, usually living in the same dwelling unit. A stratified random sampling method was used to select the households and the survey results were weighted to the right proportions for the calculations. The validity of the data can be influenced by a wide variety of survey errors due to the relatively small size and geographical coverage of the sample. Estimates for the total of South Africa are made whilst only three of the nine provinces of South Africa were included in the study. However, according to Haupt (2002), the LSM market segmentation tool has proved itself as a fairly robust wealth indicator that effectively differentiates between different consuming household classes and the results of the survey data by LSM group collected in the three provinces may be applied, to a greater or lesser extent, to the whole of South Africa. In addition since it is estimated that households in Gauteng, KwaZulu-Natal and the Western Cape were responsible for more than two thirds (69\%) of total household expenditure in South Africa in 2005, the effect of possible calculation errors for South Africa as a whole will be relatively small.

\footnotetext{
${ }^{1}$ SAARF $^{\circledR}$, SAARF SU-LSM ${ }^{\circledR}$, SAARF AMPS ${ }^{\circledR}$ are registered trademarks and where the terms SAARF, SU-LSM, LSM, AMPS are used they refer to these registered trademarks.
}

\section{TOTAL HOUSEHOLD CASH EXPENDITURE BY LSM GROUP}

Estimated total household cash expenditure by LSM group is calculated by multiplying average household expenditure by LSM group with the number of households falling into an LSM group. The main source used to calculate the number of households by LSM group is a research report by Van Aardt (2004:2) and the All Media and Products Surveys (AMPS) from 2001 to 2004 (SAARF AMPS, 2004). Table 1 shows the share in the total number of households and the total cash expenditure in South Africa by LSM group as estimated for 2005.

The comparison in table 1 clearly shows that the share in estimated total cash expenditure for the lower LSM groups is far lower than their share in total number of households. The share of households in LSM group 1 in the total number of households in South Africa is $7,8 \%$ as against an estimated share of only $0,7 \%$ in total household expenditure, while the share in the number of households of LSM group 10 is 6,5\% as against an estimated share of $30,5 \%$ in total cash expenditure. The breakeven point between the share in number of households and share in estimated total cash expenditure is LSM group 6, where the share in number of households amounts to $14,3 \%$ and the share in estimated cash expenditure to $14,4 \%$. Households falling into LSM groups 1 to 4 can be viewed as poor, mostly considered as impoverished; households in LSM group 5 to 7 as the emerging middle class; and those in higher LSMs as the wealthier class in terms of the SAARF AMPS Technical Report (SAARF AMPS, 2005:101).

Table 2 shows the share of these three groups in the estimated total household cash expenditure on the main expenditure groups.

LSM 1 to 4 households (45,9\% of all households) were responsible for $11,5 \%$ of the total household expenditure, LSM 5 to 7 households $(34,3 \%$ of all households) for $32,7 \%$ and LSM 8 to 10 households (18,9\% of all households) for $55,8 \%$. However, the picture changes considerably when it comes to the necessities of life. Almost a quarter $(24,8 \%)$ of the $\mathrm{R} 80,2$ billion spent in cash on food was spent by LSM 1 to 4 households, $38,4 \%$ by LSM 5 to 7 households and $37,1 \%$ by LSM 8 to 10 households. The opposite is true for luxury items such as holidays, where the share of LSM 1 to 4 households in the R11 billion spent on holidays was only $1,4 \%$ as against the $10,8 \%$ of LSM 5 to 7 households and $87,8 \%$ of the 8 to 10 LSM groups.

Table 3 summarises the share of the three LSM groups in total expenditure on the respective expenditure groups.

Table 3 shows that expenditure on household fuel and light by LSM groups 1-4 has the highest share in total expenditure in this category followed by food, while their share is the lowest for savings. The share of LSM groups 5-7 is the highest for dry-cleaning and 
TABLE 1: SHARE IN TOTAL NUMBER OF HOUSEHOLDS AND TOTAL CASH EXPENDITURE IN SOUTH AFRICA BY LSM GROUP, 2005

\begin{tabular}{|l|c|c|c|c|}
\hline \multirow{2}{*}{ LSM group } & \multicolumn{2}{|c|}{ Households } & \multicolumn{2}{c|}{ Cash expenditure } \\
\cline { 2 - 5 } & Number & \% million & \% \\
\hline 1 & 966855 & 7,8 & 5850 & 0,7 \\
\hline 2 & 1414831 & 11,5 & 15707 & 1,8 \\
\hline 3 & 1654435 & 13,4 & 29736 & 3,4 \\
\hline 4 & 1756531 & 14,2 & 49174 & 5,6 \\
\hline 5 & 1630889 & 13,2 & 77017 & 8,8 \\
\hline 6 & 1762835 & 14,3 & 125635 & 14,4 \\
\hline 7 & 836124 & 6,8 & 82767 & 9,5 \\
\hline 8 & 668112 & 5,4 & 79154 & 9,1 \\
\hline 9 & 859625 & 7,0 & 141534 & 16,2 \\
\hline 10 & 805918 & 6,5 & 266472 & 30,5 \\
\hline Total & $\mathbf{1 2} \mathbf{3 5 6} \mathbf{1 5 4}$ & $\mathbf{1 0 0 , 0}$ & $\mathbf{8 7 3 0 4 4}$ & $\mathbf{1 0 0 , 0}$ \\
\hline
\end{tabular}

TABLE 2: $\quad$ TOTAL HOUSEHOLD CASH EXPENDITURE AND SHARE OF LSM GROUPS BY MAIN EXPENDITURE GROUP, 2005

\begin{tabular}{|c|c|c|c|c|c|}
\hline \multirow{2}{*}{ Main expenditure group } & Total & LSM 1-4 & LSM 5-7 & LSM 8-10 & Total \\
\hline & $R^{\prime} 000$ & $\%$ & $\%$ & $\%$ & $\%$ \\
\hline Food & 180179547 & 24,5 & 38,4 & 37,1 & 100,0 \\
\hline Clothing, footwear \& accessories & 30962896 & 16,0 & 41,1 & 42,9 & 100,0 \\
\hline Housing \& electricity & 131455445 & 8,4 & 36,8 & 54,8 & 100,0 \\
\hline Household fuel \& light & 2113167 & 51,2 & 16,2 & 32,6 & 100,0 \\
\hline Transport & 89186521 & 10,6 & 28,9 & 60,5 & 100,0 \\
\hline Medical \& dental & 35609132 & 3,5 & 29,4 & 67,1 & 100,0 \\
\hline Education & 24335100 & 11,7 & 32,3 & 56,0 & 100,0 \\
\hline Insurance \& funds & 52299269 & 4,0 & 30,8 & 65,2 & 100,0 \\
\hline Recreation, entertainment \& sport & 10902742 & 1,2 & 15,0 & 83,8 & 100,0 \\
\hline Furniture \& household equipment & 24856199 & 16,8 & 36,7 & 46,5 & 100,0 \\
\hline Alcoholic beverages & 18953181 & 17,4 & 34,2 & 48,4 & 100,0 \\
\hline Cigarettes \& tobacco & 11915390 & 10,7 & 42,4 & 46,9 & 100,0 \\
\hline Washing \& cleaning materials, etc & 11870611 & 22,6 & 38,9 & 38,5 & 100,0 \\
\hline Dry-cleaning \& laundry & 379798 & 2,1 & 56,5 & 41,4 & 100,0 \\
\hline Personal care & 24626886 & 17,2 & 39,5 & 43,3 & 100,0 \\
\hline Communication & 32939801 & 8,2 & 31,1 & 60,7 & 100,0 \\
\hline Reading matter \& stationery & 5757503 & 8,2 & 40,1 & 51,7 & 100,0 \\
\hline Domestic workers & 10922064 & 1,0 & 10,3 & 88,7 & 100,0 \\
\hline Support of relatives (cash) & 2307563 & 21,2 & 53,4 & 25,4 & 100,0 \\
\hline Holiday/weekend (excl transport) & 10959210 & 1,4 & 10,8 & 87,8 & 100,0 \\
\hline Income tax & 95595140 & 0,2 & 25,6 & 74,2 & 100,0 \\
\hline Miscellaneous & 12756987 & 9,7 & 37,5 & 52,8 & 100,0 \\
\hline Savings & 52160089 & 4,7 & 23,9 & 71,4 & 100,0 \\
\hline Total & 873044252 & 11,5 & 32,7 & 55,8 & 100,0 \\
\hline
\end{tabular}


TABLE 3: SHARE OF LSM GROUPS IN TOTAL HOUSEHOLD EXPENDITURE

\begin{tabular}{|c|c|c|c|}
\hline \multirow{2}{*}{$\begin{array}{c}\text { Share } \\
\%\end{array}$} & \multicolumn{3}{|c|}{ LSM groups } \\
\hline & LSM 1-4 & LSM 5-7 & LSM 8-10 \\
\hline $71-98$ & & & $\begin{array}{l}\text { Recreation, entertainment \& sport } \\
\text { Domestic workers } \\
\text { Holidays \& weekend excursions } \\
\text { Income tax } \\
\text { Savings }\end{array}$ \\
\hline $60-69$ & & & $\begin{array}{l}\text { Transport } \\
\text { Medical \& dental } \\
\text { Insurance \& funds } \\
\text { Communication }\end{array}$ \\
\hline $50-59$ & Household fuel \& light & $\begin{array}{l}\text { Dry-cleaning \& laundry } \\
\text { Support of relatives }\end{array}$ & $\begin{array}{l}\text { Housing \& electricity } \\
\text { Education } \\
\text { Reading matter \& stationary } \\
\text { Miscellaneous items }\end{array}$ \\
\hline $40-49$ & & $\begin{array}{l}\text { Clothing, footwear \& accessories } \\
\text { Cigarettes \& tobacco } \\
\text { Reading matter \& stationary }\end{array}$ & $\begin{array}{l}\text { Clothing, footwear \& accessories } \\
\text { Furniture \& household equipment } \\
\text { Alcoholic beverages } \\
\text { Cigarettes \& tobacco } \\
\text { Dry-cleaning \& laundry } \\
\text { Personal care }\end{array}$ \\
\hline $30-39$ & & $\begin{array}{l}\text { Food } \\
\text { Housing \& electricity } \\
\text { Education } \\
\text { Insurance \& funds } \\
\text { Furniture \& household equipment } \\
\text { Alcoholic beverages } \\
\text { Washing \& cleaning materials } \\
\text { Personal care } \\
\text { Communication } \\
\text { Miscellaneous items }\end{array}$ & $\begin{array}{l}\text { Food } \\
\text { Household light \& fuel } \\
\text { Washing \& cleaning materials }\end{array}$ \\
\hline $20-29$ & $\begin{array}{l}\text { Food } \\
\text { Washing \& cleaning materials } \\
\text { Support of relatives }\end{array}$ & $\begin{array}{l}\text { Transport } \\
\text { Medical \& dental } \\
\text { Income tax } \\
\text { Savings }\end{array}$ & Support of relatives \\
\hline $10-19$ & $\begin{array}{l}\text { Clothing, footwear \& accesso- } \\
\text { ries } \\
\text { Transport } \\
\text { Education } \\
\text { Alcoholic beverages } \\
\text { Furniture \& household equip- } \\
\text { ment } \\
\text { Cigarettes \& tobacco } \\
\text { Personal care }\end{array}$ & $\begin{array}{l}\text { Household fuel \& light } \\
\text { Recreation } \\
\text { Domestic workers } \\
\text { Holidays \& weekend excursions }\end{array}$ & \\
\hline $0-9$ & $\begin{array}{l}\text { Housing \& electricity } \\
\text { Medical \& dental } \\
\text { Insurance \& funds } \\
\text { Recreation, entertainment \& } \\
\text { sport } \\
\text { Dry-cleaning \& laundry } \\
\text { Communication } \\
\text { Reading matter \& stationary } \\
\text { Domestic workers } \\
\text { Holidays \& weekend excur- } \\
\text { sions } \\
\text { Miscellaneous items } \\
\text { Income tax } \\
\text { Savings }\end{array}$ & & \\
\hline
\end{tabular}


laundry and support of relatives, while their share is less than $20 \%$ of the total household expenditure on household fuel and light, recreation, entertainment and sport, domestic workers and holiday and weekend excursions.

More than seventy per cent of all cash expenditure in 2005 can be attributed to LSM 8 to 10 households for domestic workers, holidays, recreation, entertainment and sport, income tax and savings, while their expenditure on medical and dental, insurance and funds, communication and transport represents between $60 \%$ and $69 \%$ of total expenditure. LSM 8-10 households spend between $50 \%$ and $59 \%$ of all expenditure on education, housing and electricity, miscellaneous items and reading matter and stationery. Their share in total household expenditure is lowest for support of relatives.

\section{DIFFERENCES IN EXPENDITURE ON DIFFERENT CATEGORIES OF CONSUMER GOODS AND SERVICES BY LSM 1, 6 AND 10 HOUSEHOLDS}

Differences in the expenditure patterns of households by LSM group will be illustrated in this section by making use of the expenditure figures of LSM 1, the poorest households; LSM 6, the households where the share in the number of households and in total cash expenditure is virtually equal, and LSM 10, the households with the highest living standard. Table 4 shows the average amounts and percentage distribution of LSM 1, 6 and 10 households' cash expenditure by main expenditure group.

According to table 4, substantial differences prevail between the expenditure patterns of households falling into the different LSM groups. The total household budget, excluding expenditure in kind for LSM 1 households, amounts to R6 050,53 for 2005 or R504,19 per month. The household budget for LSM 6 came to R71 268,50 for 2005 or R5 939,04 per month and that of LSM 10 to R330 643,46 or R27 553,62 per month. The major part of the cash of households falling into LSM 1 group was spent on the necessities of life. Their spending on food, clothing and housing made up R4 799,49 or $79,3 \%$ of their total cash budget as against the R32 830,62 or 46,1\% for LSM 6 and R90 691,29 or $27,4 \%$ for LSM 10 households. Expenditure on food alone constituted $70,8 \%$ of the total cash expenditure of LSM 1 households as against 24,2\% for LSM 6 and 11,2\% for LSM 10.

\section{Food}

Differences in the household budgets for main food groups also occur between the LSM households groups. Table 5 shows the distribution of LSM 1, 6 and 10 household cash expenditure on main food groups as estimated for 2005 .

Meat products top the list in table 5 with the highest percentage expenditure for all three LSM groups. Grain products are second for LSM 1 and 6 households, while prepared food $(16,9 \%)$ is second for LSM
10 households. Third for LSM 1 and LSM 6 households are vegetables with $13,1 \%$ and $11,9 \%$ respectively. After meat products $(27,8 \%)$ and prepared food $(16,9 \%)$, LSM 10 households spent virtually equal amounts on grain products $(9,6 \%)$, milk products and eggs $(9,4 \%)$, and vegetables $(9,4 \%)$. LSM 10 households also spent relatively more on fish products, fruit and nuts, non-alcoholic beverages and miscellaneous products (salt, pepper, spices, condiments etc) and relatively less on fats and oils and sugar products.

Individual food items on which households falling into the three LSM groups spent substantial amounts of their money are as follows:

Grain products Spending on different grain products is presented as a percentage of total expenditure on grain products in brackets.

LSM 1 - white bread (26\%), rice (23\%) and mealie meal (22\%).

LSM 6 - white bread $(37 \%)$ rice $(13 \%)$, brown bread $(12 \%)$, mealie meal (7\%) and cake flour $(7 \%)$.

LSM 10 - white bread (32\%), cakes and biscuits $(14 \%)$, brown bread $(12 \%)$, cereals $(9 \%)$ and rice (7\%).

Meat Spending on different meat products is presented as a percentage of total expenditure on meat products in brackets.

LSM 1 - poultry (46\%), beef (17\%) and mutton (16\%). LSM 6 - beef $(28 \%)$, poultry (24\%), mutton (22\%) and boerewors $(9 \%)$.

LSM 10 - poultry (25\%), beef (23\%), mutton (23\%) and boerewors (8\%).

Milk products and eggs Spending on different milk products and eggs is presented as a percentage of total expenditure on milk products and eggs in brackets.

LSM 1 - eggs (39\%), sour milk (30\%), fresh milk (27\%) and condensed milk (3\%).

LSM 6 - fresh milk (43\%), eggs (19\%), cheese $(9 \%)$ and yoghurt (6\%).

LSM 10 - fresh milk (45\%), cheese (16\%), eggs (9\%) and yoghurt (9\%).

Vegetables Spending on different types of vegetables is presented as a percentage of total expenditure on vegetables in brackets.

LSM 1 - cabbage (36\%), potatoes (28\%), onions (13 $5)$ and tomatoes (7\%).

LSM 6 - potatoes (16\%), carrots (10\%), onions (8\%) and pumpkin (8\%).

LSM 10 - frozen vegetables (12\%), potatoes (11\%), green beans $(8 \%)$ and carrots $(7 \%)$.

Fruit Spending on different types of fruit is presented as a percentage of total expenditure on fruit in brackets.

LSM 1 - citrus fruit (54\%) and tropical fruit (46\%). 
TABLE 4:

CASH EXPENDITURE OF LSM 1, 6 AND 10 HOUSEHOLDS BY MAIN EXPENDITURE GROUP, 2005

\begin{tabular}{|c|c|c|c|c|c|c|}
\hline \multirow{2}{*}{ Main expenditure group } & \multicolumn{2}{|c|}{ LSM 1} & \multicolumn{2}{|c|}{ LSM 6} & \multicolumn{2}{|c|}{ LSM 10} \\
\hline & $\mathbf{R}$ & $\%$ & $\mathbf{R}$ & $\%$ & $\mathbf{R}$ & $\%$ \\
\hline Food & 4284,01 & 70,81 & 17235,54 & 24,18 & 37072,65 & 11,21 \\
\hline Clothing, footwear \& accessories & 250,81 & 4,15 & 3280,80 & 4,60 & 8543,87 & 2,58 \\
\hline Housing \& electricity & 264,67 & 4,37 & 12314,28 & 17,28 & 45074,77 & 13,63 \\
\hline Household fuel \& light & 116,96 & 1,93 & 8,87 & 0,11 & 495,37 & 0,15 \\
\hline Transport & 17,25 & 0,29 & 6280,19 & 8,81 & 36422,97 & 11,02 \\
\hline Medical \& dental & 43,67 & 0,72 & 2615,18 & 3,67 & 169367,64 & 4,95 \\
\hline Education & 107,60 & 1,78 & 1999,55 & 2,81 & 9305,69 & 2,81 \\
\hline Insurance \& funds & 0,00 & - & 4256,06 & 5,97 & 23962,28 & 7,25 \\
\hline Recreation, entertainment \& sport & 0,00 & - & 339,83 & 0,56 & 7217,52 & 2,18 \\
\hline Furniture \& household equipment & 262,12 & 4,33 & 2361,93 & 3,31 & 8404,28 & 2,54 \\
\hline Alcoholic beverages & 48,31 & 0,80 & 1409,73 & 1,98 & 5570,28 & 1,68 \\
\hline Cigarettes \& tobacco & 39,18 & 0,65 & 1378,37 & 1,93 & 2331,40 & 0,71 \\
\hline Washing \& cleaning materials, etc & 234,93 & 3,88 & 1136,76 & 1,60 & 2518,83 & 0,76 \\
\hline Dry-cleaning \& laundry & 0,00 & - & 61,47 & 0,09 & 72,32 & 0,02 \\
\hline Personal care & 280,46 & 4,64 & 2400,77 & 3,37 & 6389,72 & 1,93 \\
\hline Communication & 87,79 & 1,45 & 2435,83 & 3,42 & 12826,84 & 3,88 \\
\hline Reading matter \& stationery & 0,00 & - & 489,96 & 0,69 & 1872,06 & 0,57 \\
\hline Domestic workers & 0,00 & - & 254,21 & 0,36 & 7188,28 & 2,17 \\
\hline Support of relatives (cash) & 0,00 & - & 260,69 & 0,37 & 321,51 & 0,10 \\
\hline Holiday/weekend (excl transport) & 0,00 & - & 314,62 & 0,44 & 8358,41 & 2,53 \\
\hline Income tax & 0,00 & - & 6100,20 & 8,56 & 56412,42 & 17,06 \\
\hline Miscellaneous & 12,48 & 0,21 & 1401,43 & 1,97 & 4698,60 & 1,42 \\
\hline Savings & 0,00 & - & 2799,22 & 3,93 & 29215,78 & 8,84 \\
\hline Total & 6050,23 & 100,00 & 71268,50 & 100,00 & 330643,46 & 100,00 \\
\hline
\end{tabular}

TABLE 5:

CASH EXPENDITURE ON FOOD OF LSM 1, 6 AND 10 HOUSEHOLDS BY MAIN FOOD GROUP, 2005

\begin{tabular}{|c|c|c|c|c|c|c|}
\hline \multirow{2}{*}{ Main food group } & \multicolumn{2}{|c|}{ LSM 1} & \multicolumn{2}{|c|}{ LSM 6} & \multicolumn{2}{|c|}{ LSM 10} \\
\hline & $\mathbf{R}$ & $\%$ & $\mathbf{R}$ & $\%$ & $\mathbf{R}$ & $\%$ \\
\hline Grain products & 1417,81 & 32,9 & 2722,84 & 15,8 & 3567,04 & 9,6 \\
\hline Meat products & 1596,50 & 37,4 & 6050,21 & 35,1 & 10294,04 & 27,8 \\
\hline Fish products & 14,53 & 0,3 & 451,15 & 2,6 & 1239,53 & 3,3 \\
\hline Fats \& oils & 159,77 & 3,7 & 567,59 & 3,3 & 842,64 & 2,3 \\
\hline Milk products \& eggs & 139,21 & 3,3 & 1375,93 & 8,0 & 3482,43 & 9,4 \\
\hline Vegetables & 561,03 & 13,1 & 2045,67 & 11,9 & 3498,04 & 9,4 \\
\hline Fruit \& nuts & 39,50 & 0,9 & 745,05 & 4,3 & 2304,26 & 6,2 \\
\hline Sugar products & 174,16 & 4,1 & 641,77 & 3,7 & 1325,52 & 3,6 \\
\hline Non-alcoholic beverages & 114,33 & 2,7 & 617,23 & 3,6 & 2015,20 & 5,4 \\
\hline Miscellaneous food & 67,19 & 1,6 & 892,19 & 5,2 & 2256,85 & 6,1 \\
\hline Prepared food & 0,00 & - & 1125,90 & 6,5 & 6247,08 & 16,9 \\
\hline Total & 4284,01 & 100,0 & 17235,54 & 100,0 & 37072,65 & 100,0 \\
\hline
\end{tabular}


LSM 6 - citrus fruit (29\%), fruit juices (23\%), tropical fruit (22\%) and deciduous fruit (16\%).

LSM 10 - fruit juices (27\%), citrus fruit (23\%), tropical fruit $(22 \%)$ and deciduous fruit (18\%).

Non-alcoholic beverages Spending on different types of non-alcoholic beverages is presented as a percentage of total expenditure on non-alcoholic beverages in brackets.

LSM 1 - instant coffee (57\%), tea (38\%) and rooibos or herbal tea (5\%).

LSM 6 - instant coffee (37\%), tea (22\%), fruit squashes (10\%) and cold drinks (9\%).

LSM 10 - cold drinks (34\%), instant coffee (17\%), tea $(10 \%)$ and energy drinks (10\%).

Miscellaneous food Spending on different types of miscellaneous food products is presented as a percentage of total expenditure on miscellaneous food products in brackets.

LSM 1 - soups in packets (43\%), curry powder (13\%), gravy powder (13\%) and tomato sauce (11\%).

LSM 6 - mayonnaise (11\%), tomato sauce (10\%), curry powder (10\%) and soups in packets (9\%).

LSM 10 - oven-ready dishes and meals (17\%), dried potato chips and cheese curls (14\%), tomato sauce (7\%) and mayonnaise (7\%).

The above exposition of household expenditure on food clearly illustrates that households in LSM group 1 spend their money on a smaller variety of foodstuffs and are limited to the most basic items to get the most value for their money. The expenditure pattern of LSM group 6 households shows greater resemblance to the spending patterns of LSM 10 households than to those of LSM 1 households, although they also have to limit their expenditure to more essential and fewer luxury food items.

\section{Clothing and footwear}

Turning to clothing and footwear, school uniforms top the list of LSM 1 households' expenditure in this product group, followed by women's jeans, jackets and underwear. Women's shoes top the list in the clothing and footwear budget of LSM 6 households followed by men's tackies, jeans and shoes. LSM 10 households spent most of their clothing budget on women's shoes, men's shoes, men's shirts and men's jeans.

\section{Transport}

The average annual transport budget of only R17,25 for LSM 1 households is devoted to public transport (mostly taxis) as against $55 \%$ of the transport budget of R6 280,19 of LSM 6 households and only 5\% of the transport budget of R36 422,97 of LSM 10 households. The most important expenditure items in the transport budget of LSM 6 households are taxis $(29,3 \%$ of their total transport budget), fuel for own vehicles $(22,1 \%)$ and bus fare $(11,6 \%)$. LSM 10 households spend $42,6 \%$ of their transport budget on fuel while a further $19,1 \%$ goes to payments on motor vehicles.

\section{Medical and dental}

Almost all (98\%) the medical and dental expenditure by LSM 1 households is devoted to patent medicine, mostly laxatives and cough mixtures, while LSM 6 households spend only $13 \%$ of their medical budget on patent medicine. Contributions to medical or sick benefit funds (72\%) and private doctors' fees (9\%) are the major medical expenditure items for LSM 6 households. Contributions to medical or sick benefit funds constitute $81 \%$ and private doctors' fees $5 \%$ of the medical budgets of LSM 10 households.

\section{Recreation, entertainment and sport}

LSM 1 households do not spend money on recreation, entertainment and sport. TV licenses and admission fees to bioscopes top the list in LSM 6 households' budgets for this item, while expenditure on DSTV, MNet, membership fees for health and fitness clubs and admission fees to bioscopes are the major expenditure items for LSM 10 households.

\section{Furniture and household equipment}

LSM 1 households spend an average of R262,12, LSM 6 R2 361,93 and LSM 10 R8 404,28 per year on furniture and household equipment. Blankets are the major expenditure items in the furniture and household equipment budget of LSM 1 households as against bedroom furniture for LSM 6 households and computers and printers for LSM 10 households.

\section{Alcoholic beverages}

On average, LSM 1 households spend R48,31, LSM 6 R1 409,73 and LSM 10 R5 570,28 per year on alcoholic beverages. Both LSM 1 and 6 households spend most of their alcoholic beverage budgets on beer, while wine tops the list for LSM 10 households.

\section{Washing and cleaning materials}

LSM 1 households spend an average of R234,93, LSM 6 R1 136,76 and LSM 10 R2 518,83 per year on washing and cleaning materials. Soap powder is the major expenditure item in the washing and cleaning budgets of all three LSM groups of households.

\section{Personal care}

On average, LSM 1 households spend R280,46, LSM 6 R2 499,77 and LSM 10 R 6,389,72 per year on personal care. Toothbrushes and toothpaste top the list for the personal care budgets of LSM 1 households, deodorants and perfumes for LSM 6 households, and haircuts and beauty services of females for LSM 10 households.

\section{Communication}

LSM 1 households spend an average of R87,79, LSM 6 R2 435,83 and LSM 10 R12 826,84 per year on communication. Payment for telephone calls is the major communication expenditure item for LSM 1 
households, while cellular phone calls top the list for LSM 6 and 10 households.

\section{Miscellaneous items}

On average, LSM 1 households spend R12,48, LSM 6 R1 401,43 and LSM 10 R4 698,60 per year on miscellaneous goods and services. Funeral expenses and lotteries top the list under miscellaneous items for LSM 1 households, casinos/gambling tables and lotteries for LSM 6 households and church contributions and lotteries for LSM 10 households.

\section{SUMMARY AND CONCLUSION}

As mentioned earlier, there are various options for the classification of households according to living standards. In this article, households were classified according to the SU-LSM method of classification where household assets, access to services and geographical location constitute indicators. Average household cash expenditure was multiplied by the number of households in each LSM group to determine total household expenditure for 2005. A comparison of the share of households in the number of households by LSM group with the share in total household expenditure shows that LSM 1 to 5 households spend less than their share in the total number of households in the group, while the share in total household expenditure and total number of households for LSM group 6 is virtually equal and LSM 7 to 10 households command a higher share in spending than in the number of households. The expenditure pattern of LSM 1 households shows that virtually their entire household budget is devoted to the bare necessities of life while LSM 6 households are able to purchase a number of luxuries and LSM 10 households have considerable funds available for discretionary spending.

In conclusion, it can be said that South Africa is still in the unfortunate position where many people fall into the lower standards of living categories and a special effort should be made to raise the standard of living of these people and to support them through education to spend the little money they have as effectively as possible.

\section{REFERENCES}

ABRAHAM, JH. 1977. The origins and growth of sociology. Harmondsworth. Penguin Books.

HAUPT, P. 2002. LSMs: Twelve years of continuous development. Paper delivered at the Annual Research Review of the Bureau of Market Research, Pretoria, October 2002.

KEYNES, JM. 1936. The general theory of employment, interest and money. Available on line. URL: www.marxist.org/reference/subject/economics/keynes/ general-theoryl

MARX, K. 1981. Economic and philosophic manuscripts of 1844. Moscow. Progress publishers.

NARAYAN, D, CHAMBERS, R, SHAH, MK \& PETESCH, P. 2000. Voices of the poor: Crying out for change. Oxford. Oxford University Press/World Bank.

NARAYAN, D, PATEL, R, SCHAFFT, K, RADEMACHER, A \& KOCH-SCHULTE, S. 2000. Voices of the poor: Can anyone hear us? Oxford. Oxford University Press/World Bank.

PLATO. 1983. The Republic. Harmondsworth. Penguin Books.

SUMMERS, R \& HESTON, A. 1995. Standard of living: An alternative measure of nations' current material wellbeing. Pennsylvania. The University of Pennsylvania.

South African Advertising Research Foundation. (SAARF) 2002. SAARF® All Media and Products Survey. AMPS ${ }^{\circledR}$ 2000. Technical report. Vol 1. Bryanston.

South African Advertising Research Foundation (SAARF). 2004. Electronic AMPS ${ }^{\circledR}$ database. Bryanston.

South African Advertising Research Foundation (SAARF). 2005. Living Standards Measure. Available on line. URL: www.saarf.co.za .

VAN AARDT, C. 2004. A projection of the South African population, 2001 to 2021. Pretoria. Unisa, Bureau of Market Research. Research Report 330. 